INFO ARTIKEL

Riwayat Artikel:

Diterima : 9 Juni 2019

Disetujui : : 10 Agustus 2019

\title{
PENDIDIKAN
}

\section{PENGEMBANGAN LKS BERBASIS LEARNING CYCLE 5E PADA MATERI LITOSFER}

\author{
Dwi Kurniawati ${ }^{1}$, Yuli Ifana Sari ${ }^{2}$, Aris Efendi ${ }^{3}$ \\ ${ }^{1-3}$ Universitas Kanjuruhan Malang \\ $(\bowtie)$ dwikur@unikama.ac.id ${ }^{1}$; ifana@unikama.ac.id ${ }^{2}$; arise025@ gmail.com³
}

\begin{abstract}
ABSTRAK
Hasil studi menunjukkan bahwa LKS merupakan bahan ajar yang sering digunakan di sekolah. Peningkatan mutu bahan ajar harus terus ditingatkan dengan melakukan penelitian pengembangan dengan tujuan untuk menghasilkan roduk LKS geografi berbasis learning cycle $5 E$ pada materi Litosfer. Rancangan pengembangan penelitian ini menggunakan mode Borg and Gall, yaitu pengembangan desain pembelajaran, produk LKS, dan evaluasi. Subjek penelitiannya adalah siswa kelas X IPS, dan ada 2 validator dari dosen yang telah berpengalaman dalam mengembangkan LKS. Data dikumpulkan dengan angket validasi untuk validator dan angket yang berupa respon dari penggunaan LKS untuk siswa dan guru. Analisis dilakukan secara deskriptif. Hasil pengembangan LKS menunjukkan bahwa ada kelayakan isi/materi memilii kriteria baik, penyajian media sangat baik, dan bahasa dengan kategori baik. Hasil uji coba kelompok kecil memiliki rata-rata nilai 3,1 dengan kategori tinggi dan rata-rata nilai untuk kelompok besar sebesar 3 dengan kategori tinggi. LKS berbasis learning cycle 5E mendapatkan respon dari guru sebesar 3,3 dengan kategori tinggi.
\end{abstract}

Kata Kunci : Pengembangan LKS, Learning Cycle 5E, Litosfer

\section{PENDAHULUAN}

Geografi adalah ilmu yang mempelajari tentang lokasi serta persamaan, dan perbedaan (variasi) keruangan atas fenomena fisik, dan manusia di atas permukaan bumi. Menurut hasil Seminar dan Lokakarya Ikatan Geografi Indonesia (IGI) di Semarang tahun 1988; Geografi adalah ilmu yang mempelajari persamaan dan perbedaan fenomena geosfer dengan sudut pandang kelingkungan dan kewilayahan dalam konteks keruangan. Fenomena geosfer yang dipelajari yaitu hidrosfer, litosfer, atmosfer, biosfer, dan antroposfer.

Fenomena geosfer tersebut mengkaji aspek fisik (hidrosfer, litosfer, atmosfer, biosfer) dan aspek sosial. Pada aspek fisik memusatkan pada geografi sebagai ilmu bumi, menggunakan biologi untuk memahami pola flora, fauna, matematika, dan fisika untuk memahami pergerakan bumi, dan hubungannya dengan anggota tata surya yang lain. Termasuk juga di dalamnya ekologi muka bumi dan geografi lingkungan. Sedangkan aspek sosial mengkaji bagaimana manusia beradaptasi dengan wilayahnya dan manusia lainnya, dan pada transformasi makroskopis bagaimana manusia berperan di dunia. Bisa dibagi menjadi: geografi ekonomi, geografi politik (termasuk geopolitik), geografi sosial (termasuk geografi kota), geografi feminisme dan geografi militer.

Pembelajaran di sekolah matapelajaran geografi kelas $\mathrm{X}$ (sepuluh) semester 1 salah satunya mempelajari materi litosfer sesuai dengan 
kurikulum 2013. Materi litosfer yang diajarkan guna mencapai kompetensi dasar 3.4 yakni menganalisis hubungan antara manusia dengan lingkungan sebagai akibat dari dinamika litosfer. Untuk mencapai kompetensi dasar tersebut terdapat sub-sub pokok yang harus dipelajari antara lain struktur lapisan kulit bumi dan pemanfaatannya, batuan penyusun kulit bumi, bentuk permukaan bumi sebagai akibat vulkanisme, seisme, dan diatropisme, ciri-ciri bentang alam akibat proses pengikisan dan pengendapan, degradasi lahan dan pengaruhnya bagi kehidupan.

Berdasarkan penjelasan sebelumnya, materi litosfer adalah salah satu materi geografi fisik yang dalam pemahamannya membutuhkan pembelajaran secara kontekstual. Hal ini dikarenakan banyak konsep konkrit yang dipelajari. Dalam mempelajari geografi fisik maka harus menguasai kumpulan pengetahuan yang berupa fakta, konsep, atau prinsip, membahas tentang fakta serta gejala alam. Fakta dan gejala alam tersebut menjadikan pembelajaran tidak hanya verbal tetapi juga faktual. Oleh karena itu, materi litosfer perlu diajarkan dengan bantuan learning cycle karena banyak konsep konkrit yang dipelajari. Pembelajaran berbasis learning cycle akan mengajak siswa mengidentifikasi langsung dengan cara mengeksplorasi dimana siswa dapat melakukan pengamatan, mengumpulkan data, hingga mencapai sebuah kesimpulan.

Learning cycle $5 \mathrm{E}$ adalah siklus belajar yang terdiri dari 5 tahapan yaitu engagement, exploration, explanation, elaboration, dan evaluation. Tahap engagement adalah tahap persiapan dan pembangkitan minat siswa. Exploration adalah tahap yang bertujuan untu mengecek pengetahuan siwa. Explanation adalah tahap dimana siswa harus dapat menjelaskan suatu konsep dengan kalimat atau pemikiran sendiri. Tahap elaboration adalaha tahap dimana siswa menerapkan konsep dan keterampilan konsep yang telah dipelajari. Tahap evaluation adalah tahap dimana siswa dapat mengeevaluasi diri dengan mengajukan pertanyaan terbuka dan mencari jawaban yang menggunakan oberservasi.
Pembelajaran dengan menggunakan model learning cycle 5E akan membantu siswa dalam membangun pengetahuan yang telah diperoleh melalui aktifitas yang telah dilakukan dalam pembelajaran. Model ini akan memacu siswa untuk berperan aktif dalam pembelajaran sehingga pembelajaran berpusan pada siswa. Khanifatul (2013) menjelaskan bahwa "prinsip student centered menekankan pada pembelajaran akan lebih berhasil apabila siswa secara aktif melakukan latihan-latihan secara langsung dan relevan dengan tujuan pembelajaran yang sudah ditetapkan".

Pembelajaran dengan menggunakan model learning cycle $5 \mathrm{E}$ pada dasarnya menekankan keaktifan siswa dalam mengikuti pembelajaran. Model ini juga mengutamakan proses dalam pemahaman konsep dan kegiatan pembelajaran yang meliputi kegiatan mengobservasi, merumuskan pertanyaan yang relevan dan membangun konsep baru berdasarkan pengetahuan dan pemahaman yang telah didapat selama pembelajaran. Kegiatan tersebut bertujuan untuk mengembangkan keterampilan ilmiah anak sehingga dengan model learning cycle 5E diharapkan pembelajaran dapat dilakukan secara maksimal dan mendorong siswa menjadi lebih aktif.

Pembelajaran dapat dilakukan dengan maksimal tidak hanya dengan bantuan model learning cycle 5E tetapi perlu adanya bahan ajar yang mendukung proses pembelajaran. Bahan ajar merupakan salah satu sarana guna membantu memahamkan siswa dalam belajar. Melalui bahan ajar, diharapkan dapat meningkatkan minat, motivasi, dan hasil belajar serta membiasakan kemandirian untuk memperolah pengetahuan tanpa atau didampingi guru.

Salah satu bahan ajar yang dapat membantu meningkatkan hasil belajar siswa adalah Lembar Kerja Siswa (LKS). Lembar kerja siswa merupakan salah satu bahan ajar cetak berupa lembar-lembar kertas yang berisi materi, ringkasan, dan petunjuk-petunjuk pelaksanaan tugas pembelajaran yang harus dikerjakan oleh siswa sesuai dengan kompetensi dasar yang akan dicapai. Prastowo (2011) menjelaskan bahwa 
"LKS juga berfungsi sebagai bahan ajar yang mempermudah siswa untuk memahami materi yang ringkas dan kaya akan tugas untuk berlatih serta mempermudah pelaksanaan pembelajaran kepada siswa".

\section{METODOLOGI PENELITIAN}

Penelitian ini bertujuan untuk mengembangkan Lembar Kerja Siswa (LKS) berbasis learning cycle $5 \mathrm{E}$ pada materi litosfer untuk siswa kelas X SMA/MA. Langkah-langkah yang digunakan dalam penelitian ini mengadaptasi pada langkah-langkah menurut model Borg and Gall.

Pengembangan dan penyusunan Lembar Kerja Siswa (LKS) berbasis learning cycle 5E ini merupakan modifikasi dari sepuluh langkah menjadi tiga langkah pengembangan. Prosedur pengembangan dapat dilihat pada gambar 1 berikut ini.

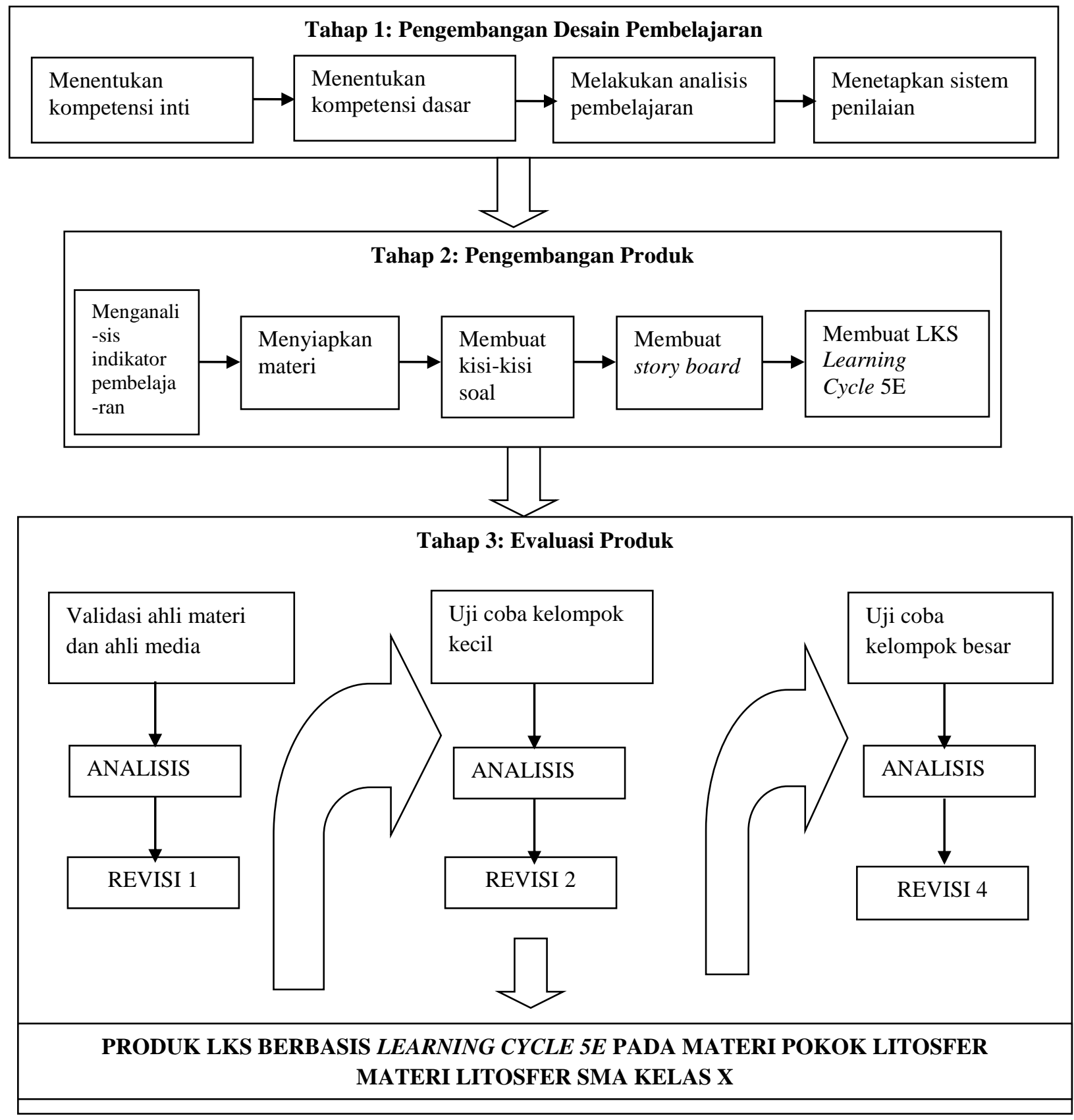


Berdasarkan gambar 1 dijelaskan tahaptahap pengembangan sebagai berikut:

\section{Pengembangan Desain Pembelajaran}

1) menentukan Kompetensi Inti (KI): memahami, menerapkan, menganalisis pengetahuan faktual, konseptual, prosedural berdasarkan rasa ingintahunya tentang ilmu pengetahuan, teknologi, seni, budaya, dan humaniora dengan wawasan kemanusiaan, kebangsaan, kenegaraan, dan peradaban terkait penyebab fenomena dan kejadian, serta menerapkan pengetahuan prosedural pada bidang kajian yang spesifik sesuai dengan bakat dan minatnya untuk memecahkan masalah; 2) menentukan Kompetensi Dasar (KD): menganalisis hubungan antara manusia dengan lingkungan sebagai akibat dari dinamika litosfer; 3) melakukan analisis pembelajaran; 4) berdasarkan analisis literatur buku geografi kelas $\mathrm{X}$, diperoleh informasi tentang kebutuhan siswa untuk materi yang membutuhkan Lembar Kerja Siswa (LKS) yang berkaitan dengan materi geografi yakni litosfer.

\section{Menetapkan sistem penilaian}

1) Pengembangan Produk: menganalisis indikator pembelajaran, menyiapkan materi, membuat kisi-kisi soal, membuat story board (Story board ini merupakan tampilan dari LKS. Tujuan dari pembuatan story board ini adalah merancang secara spesifikasi secara rinci mengenai gaya dan kebutuhan material untuk pengembangan membuat LKS), membuat LKS berbasis learning cycle 5E untuk materi litosfer;
2) Evaluasi Produk: validasi ahli materi dan media, analisis setelah divalidasi, revisi produk awal (1), uji coba pertama pada kelompok kecil, analisis setelah uji coba, uji coba kedua pada kelompok besar, analisis setelah uji coba, revisi produk (2).

Setelah dua tahap selesai, maka produk Lembar Kerja Siswa (LKS) berbasis learning cycle 5E siap didesiminaksikan kepada para pengguna dan profesional melalui forum pertemuan atau menuliskan dalam jurnal nasioanal baik yang tidak terakreditasi maupun yang terakreditasi.

Setelah rancangan produk selesai dan divalidasi maka dilakukan uji coba produk. Uji coba ini bertujuan untuk mengetahui apakah produk yang dibuat layak digunakan atau tidak. Uji coba produk juga melihat sejauh mana produk yang dibuat dapat mencapai sasaran dan tujuan. 1) Desain Uji Coba, uji coba dilakukan dua kali yaitu pada kelompok kecil (6 siswa) dan kelompok besar (1 kelas); 2) Subjek Uji Coba, subjek uji coba yaitu siswa kelas X IPS.

Data yang digunakan dalam pengembangan Lembar Kerja Siswa (LKS) berbasis learning cycle $5 \mathrm{E}$ adalah data kuantitatif yang selanjutnya diubah menjadi data kualitatif dengan teknik diskriptif kualitatif persentase. Data tersebut diperoleh dari angket dan tes.

Instrumen pengumpulan data yang digunakan untuk mengetahui tingkat kevalidan produk dan keefektifan LKS berbasis learning cycle 5E dapat dilihat pada tabel 1 berikut.

Tabel 1. Instrumen dan Sumber Data

\begin{tabular}{|c|c|c|c|}
\hline $\begin{array}{c}\text { Aspek yang } \\
\text { dinilai }\end{array}$ & Instrumen & Data yang diamati & Sumber Data \\
\hline
\end{tabular}




\begin{tabular}{|c|c|c|c|}
\hline Kevalidan LKS & $\begin{array}{l}\text { a. Lembar Validasi } \\
\text { Kelayakan Isi } \\
\text { b. Lembar Validasi } \\
\text { Penyajian } \\
\text { c. Lembar Validasi } \\
\text { Kebahasaan } \\
\text { d. Lembar Validasi } \\
\text { Kegrafikan }\end{array}$ & Kevalidan LKS & Validator \\
\hline \multirow[t]{2}{*}{ Keefektifan LKS } & a. Angket & $\begin{array}{l}\text { Kesesuaian materi, penggunaan } \\
\text { bahasa, ketepatan konsep, desain, } \\
\text { kejelasan gambar, keseluruhan } \\
\text { pemahaman siswa }\end{array}$ & $\begin{array}{l}\text { Guru } \\
\text { Siswa }\end{array}$ \\
\hline & $\begin{array}{l}\text { b. Soal evaluasi pada } \\
\text { LKS }\end{array}$ & Hasil evaluasi & Siswa \\
\hline
\end{tabular}

Angket tanggapan guru dan siswa terdapat lima aspek dengan total enam belas indikator penilaian. Kelima aspek tersebut antara lain: 1) pembangkitan minat (engagement), 2) eksplorasi (exploration), 3) menjelaskan (explaination),4) mengelaborasi (elaboration), dan 5) mengevaluasi (evaluation). Analisis statistik deskriptif digunakan untuk mengolah data yang diperoleh dalam bentuk analisis persentase dari angket dan tes yang diberikan pada siswa dan guru. Kesimpulan data yang diperoleh ditentukan dengan kriteria kelayakan produk pada table 2 berikut.

Tabel 2. Tingkat Kriteria Persentase LKS Berbasis Learning Cycle 5E

\begin{tabular}{lll}
\hline $\begin{array}{l}\text { Tingkat } \\
\text { Pencapaian }\end{array}$ & Kualifikasi & Keterangan \\
\hline $81 \%-100$ & Sangat baik & $\begin{array}{l}\text { Tidak perlu } \\
\text { revisi } \\
\%\end{array}$ \\
$61 \%-80 \%$ & Baik & $\begin{array}{l}\text { Tidak perlu } \\
\text { revisi }\end{array}$ \\
& & Revisi \\
$41 \%-60 \%$ & Cukup & Revisi \\
$21 \%-40 \%$ & Kurang & Revisi \\
$0 \%-20 \%$ & Sangat & \\
\hline & Kurang & \\
\hline
\end{tabular}

Sumber: (BSNP, 2006)

Tabel 3. Kategori Respon Siswa dan Guru

\begin{tabular}{llll}
\hline No & $\begin{array}{l}\text { Rata-rata } \\
\text { Respon } \\
\text { dan Dosen }\end{array}$ & $\begin{array}{r}\text { Skor } \\
\text { Siswa }\end{array}$ & Kategori \\
\hline 1. & $3 \leq \overline{\mathrm{X}} \leq 4$ & Tinggi \\
2. & $2 \leq \overline{\mathrm{X}}<3$ & Sedang \\
3. & $1 \leq \overline{\mathrm{X}}<2$ & Rendah \\
\hline
\end{tabular}

Sumber: (Turmudi, 2016)

\section{HASIL DAN PEMBAHASAN}

\section{Hasil Penelitian}

Berdasarkan data yang diperoleh pada saat pelaksanaan penelitian pengembangan LKS geografi berbasis learning cycle $5 E$ terdapat hasil penelitian yang diperoleh yakni data hasil evaluasi produk dan data hasil uji lapangan.

1. Data Hasil Evaluasi Produk

Penelitian ini menghasilkan produk berupa LKS berbasis learning cycle $5 E$ pada materi litosfer. Berdasarkan prosedur yang telah dipaparkan maka hasil evaluasi produk diperoleh dari dua validator yaitu validator ahli materi dan media yang merupakan dosen Program Studi Pendidikan Geografi Universitas Kanjuruhan Malang. Berdasarkan hasil validasi masing-masing validator dengan menggunakan instrumen berupa angket uji validitas, diperoleh tabel sebagai berikut.

Tabel 4. Hasil Validasi Lembar Kerja Siswa (LKS) Berbasis Learning Cycle $5 E$

\begin{tabular}{llll}
\hline No & $\begin{array}{l}\text { Komponen } \\
\text { Penilaian }\end{array}$ & $\begin{array}{l}\text { Nilai } \\
\text { Validitas } \\
(\boldsymbol{\%})\end{array}$ & Kriteria \\
\hline 1 & $\begin{array}{l}\text { Kelayakan } \\
\text { isi/materi }\end{array}$ & 78,18 & Baik \\
2 & Penyajian/media & 88,57 & $\begin{array}{l}\text { Sangat } \\
\text { Baik }\end{array}$
\end{tabular}




\begin{tabular}{llll}
3 & Kebahasaan & 88 & Sangat \\
4 & Kegrafikan & 74,67 & Baik \\
5 & Total & 329,42 & - \\
\hline & Rata-rata & $\mathbf{8 , 6 7}$ & - \\
\hline
\end{tabular}

Hasil validasi oleh ahli materi dan media pada tabel 4 menunjukkan bahwa LKS berbasis learning cycle $5 E$ yang dikembangkan baik dengan nilai rata-rata keseluruhan dari segi kelayakan isi, penyajian, bahasa, dan kegrafikan sebesar 8,67\% .

\section{Data Hasil Uji Coba Lapangan}

Uji coba lapangan dilakukan setelah LKS divalidasi oleh ahli materi, media dan guru geografi. Selanjutnya LKS diujicobakan secara terbatas pada siswa yaitu uji coba kelompok kecil terdiri dari 6 siswa dan kelompok besar terdiri dari 16 siswa (siswa 1 kelas) kelas X IPS di MA Khairuddin. Data Hasil Uji Coba Kelompok Kecil

Uji coba kelompok kecil dimaksudkan untuk mengetahui kefektifan LKS berbasis learning cycle $5 E$ pada materi litosfer. Uji coba kelompok kecil dengan melibatkan 6 siswa yang dipilih secara heterogen berdasarkan kemampuan di kelas dan jenis kelamin kemudian siswa diberi angket untuk menilai kefektifan LKS. Uji kelompok kecil dilakukan di MA Khairuddin pada tanggal 29 Agustus 2018 hasil uji coba kelompok kecil dapat dilihat pada tabel sebagai berikut:

\section{Tabel 5. Hasil Uji Coba Kelompok Kecil}

\begin{tabular}{|c|c|c|c|c|}
\hline No & Aspek yang Ditanyakan & $\begin{array}{l}\text { Jumlah } \\
\text { Skor }\end{array}$ & $\begin{array}{c}\text { Rata- } \\
\text { rata }\end{array}$ & Kriteria \\
\hline 1 & $\begin{array}{l}\text { Mata pelajaran geografi membutuhkan lembar kerja siswa } \\
\text { untuk memudahkan pemahaman materi }\end{array}$ & 18 & 3,2 & Tinggi \\
\hline 2 & $\begin{array}{l}\text { Lembar kerja siswa berbasis learning cycle } 5 E \text { yang } \\
\text { disampaikan sesuasi dengan materi litosfer }\end{array}$ & 21 & 3,5 & Tinggi \\
\hline 3 & $\begin{array}{l}\text { Lembar kerja siswa materi litosfer mudah digunakan dalam } \\
\text { pembelajaran di kelas }\end{array}$ & 18 & 3 & Tinggi \\
\hline 4 & $\begin{array}{l}\text { Lembar kerja siswa yang dikembangkan dapat membantu } \\
\text { siswa untuk belajar mandiri di rumah }\end{array}$ & 19 & 3,2 & Tinggi \\
\hline 5 & $\begin{array}{l}\text { Penggunaan LKS pada berbasis learning cycle } 5 E \text { pada materi } \\
\text { litosfer dapat membantu Anda dalam memahami materi }\end{array}$ & 18 & 3 & Tinggi \\
\hline 6 & $\begin{array}{l}\text { Suasana pembelajaran dengan menggunakan LKS berbasis } \\
\text { learning cycle } 5 E \text { lebih menyenangkan }\end{array}$ & 18 & 3 & Tinggi \\
\hline 7 & $\begin{array}{l}\text { Penggunaan LKS berbasis learning cycle } 5 E \text { dapat } \\
\text { meningkatkan pemahaman konsep materi litosfer }\end{array}$ & 19 & 3,2 & Tinggi \\
\hline 8 & $\begin{array}{l}\text { Terdapat kesulitan dalam memahami materi litosfer pada LKS } \\
\text { berbasis learning cycle } 5 E\end{array}$ & 19 & 3,2 & Tinggi \\
\hline 9 & $\begin{array}{l}\text { Kalimat yang digunakan dalam LKS berbasis learning cycle } \\
5 E \text { mudah dipahami }\end{array}$ & 20 & 3,3 & Tinggi \\
\hline 10 & $\begin{array}{l}\text { Gambar-gambar yang terdapat dalam LKS berbasis learning } \\
\text { cycle } 5 E \text { dapat memudahkan Anda dalam memahami materi } \\
\text { litosfer }\end{array}$ & 17 & 2,8 & Sedang \\
\hline 11 & $\begin{array}{l}\text { Penggunaan LKS berbasis learning cycle } 5 E \text { pada materi } \\
\text { litosfer dapat memotivasi siswa untuk belajar dengan baik }\end{array}$ & 18 & 3 & Tinggi \\
\hline 12 & $\begin{array}{l}\text { Diperlukan penggunaan LKS berbasis learning cycle } 5 E \text { pada } \\
\text { materi geografi selanjutnya }\end{array}$ & 20 & 3,3 & Tinggi \\
\hline
\end{tabular}




\section{Jumlah}

226

3,1 Tinggi

Berdasarkan respon siswa pada tabel 5 di atas, diperoleh rata-rata 3,1 dengan kriteria yang dicapai yakni tinggi. Hal ini berarti LKS berbasis learning cycle $5 E$ yang dikembangkan oleh peneliti mempunyai kriteria sesuai untuk digunakan sebagai salah satu bahan ajar dalam pembelajaran geografi pada materi litosfer untuk kelas X.

a. Data Hasil Uji Coba Kelompok Besar

Uji coba kelompok besar dilakukan setelah mendapatkan hasil uji coba kelompok kecil dengan tujuan mengetahui tingkat kefektifan LKS berbasis learning cycle $5 E$ secara luas. Jumlah responden pada uji kelompok besar ini yakni 16 siswa kelas X IPS di MA Khairuddin yang dilaksanakan pada tanggal 6 September 2018 dengan cara memberi angket. hasil uji coba kelompok besar dapat dilihat pada tabel sebagai berikut:

Tabel 6. Hasil Uji Coba Kelompok Besar

\begin{tabular}{|c|c|c|c|c|}
\hline No & Aspek yang Ditanyakan & $\begin{array}{c}\text { Jumlah } \\
\text { Skor }\end{array}$ & $\begin{array}{c}\text { Rata- } \\
\text { rata }\end{array}$ & Kriteria \\
\hline 1 & $\begin{array}{l}\text { Mata pelajaran geografi membutuhkan lembar kerja } \\
\text { siswa untuk memudahkan pemahaman materi }\end{array}$ & 51 & 3 & Tinggi \\
\hline 2 & $\begin{array}{l}\text { Lembar kerja siswa berbasis learning cycle } 5 E \text { yang } \\
\text { disampaikan sesuasi dengan materi litosfer }\end{array}$ & 52 & 3,1 & Tinggi \\
\hline 3 & $\begin{array}{l}\text { Lembar kerja siswa materi litosfer mudah digunakan } \\
\text { dalam pembelajaran di kelas }\end{array}$ & 50 & 2,9 & Sedang \\
\hline 4 & $\begin{array}{l}\text { Lembar kerja siswa yang dikembangkan dapat } \\
\text { membantu siswa untuk belajar mandiri di rumah }\end{array}$ & 55 & 3,2 & Tinggi \\
\hline 5 & $\begin{array}{l}\text { Penggunaan LKS pada berbasis learning cycle } 5 E \text { pada } \\
\text { materi litosfer dapat membantu Anda dalam memahami } \\
\text { materi }\end{array}$ & 55 & 3,2 & Tinggi \\
\hline 6 & $\begin{array}{l}\text { Suasana pembelajaran dengan menggunakan LKS } \\
\text { berbasis learning cycle } 5 E \text { lebih menyenangkan }\end{array}$ & 54 & 3,2 & Tinggi \\
\hline 7 & $\begin{array}{l}\text { Penggunaan LKS berbasis learning cycle } 5 E \text { dapat } \\
\text { meningkatkan pemahaman konsep materi litosfer }\end{array}$ & 52 & 3,1 & Tinggi \\
\hline 8 & $\begin{array}{l}\text { Terdapat kesulitan dalam memahami materi litosfer pada } \\
\text { LKS berbasis learning cycle } 5 E\end{array}$ & 50 & 2,9 & Sedang \\
\hline 9 & $\begin{array}{l}\text { Kalimat yang digunakan dalam LKS berbasis learning } \\
\text { cycle } 5 E \text { mudah dipahami }\end{array}$ & 50 & 2,9 & Sedang \\
\hline 10 & $\begin{array}{l}\text { Gambar-gambar yang terdapat dalam LKS berbasis } \\
\text { learning cycle } 5 E \text { dapat memudahkan Anda dalam } \\
\text { memahami materi litosfer }\end{array}$ & 52 & 3,1 & Tinggi \\
\hline 11 & $\begin{array}{l}\text { Penggunaan LKS berbasis learning cycle } 5 E \text { pada materi } \\
\text { litosfer dapat memotivasi siswa untuk belajar dengan } \\
\text { baik }\end{array}$ & 49 & 2,9 & Sedang \\
\hline 12 & $\begin{array}{l}\text { Diperlukan penggunaan LKS berbasis learning cycle } 5 E \\
\text { pada materi geografi selanjutnya }\end{array}$ & 50 & 2,9 & Sedang \\
\hline & Jumlah & 620 & 3 & Tinggi \\
\hline
\end{tabular}

Hasil uji coba kelompok besar pada tabel 6 memperoleh rata-rata 3 dengan kriteria "tinggi". Hal ini menunjukkan bahwa LKS berbasis learning cycle $5 E$ yang dikembangkan oleh peneliti mempunyai kriteria sangat efektif untuk digunakan sebagai salah satu bahan ajar dalam pembelajaran pada mata pelajaran geografi dengan materi litosfer untuk kelas X.

b. Uji Coba guru 
Setelah melakukan uji coba kelompok kecil dan uji coba kelompok besar, kemudian produk diujicobakan kembali ke guru. Uji coba guru ini dilakukan untuk meyakinkan data dan mengetahui kefektifan produk secara luas. Responden uji guru ini berjumlah 1 guru IPS MA Khairuddin kelas $X$ dengan cara memberi angket untuk mengetahui respon guru terhadap kefektifan LKS berbasis learning cycle $5 E$. Hasil uji coba guru memperoleh skor 3,3 dengan kriteria yang dicapai yaitu "tinggi". Hal ini berarti LKS yang dikembangkan oleh peneliti mempunyai kriteria efektif untuk digunakan sebagai salah satu bahan ajar dalam pembelajaran materi litosfer untuk kelas $\mathrm{X}$ SMA

\section{Pembahasan}

Kompetensi dasar yang digunakan dalam penelitian ini adalah menganalisis dinamika litosfer dan dampaknya terhadap kehidupan. Kompetensi tersebut merupakan kompetensi pada aspek pengetahuan karena bertujuan untuk mengetahui hasil belajar siswa. Adapun hasil penjabaran indikatornya, antara lain: 1) menganalisis interaksi manusia dengan alam yang dipengaruhi oleh aktivitas tektonis; 2) membedakan gerak epirogenesa dengan gerak orogenesa; 3) Menganalisis interaksi manusia dengan alam yang dipengaruhi oleh aktivitas vulkanis; 4) menganalisis interaksi manusia dengan alam yang dipengaruhi oleh aktivitas seisme; 5) membuat sajian tentang interaksi manusia dengan alam yang dipengaruhi oleh aktivitas tektonis melalui gambar; 6) membuat sajian tentang interaksi manusia dengan alam yang dipengaruhi oleh aktivitas vulkanis melalui gambar; 7) membuat sajian tentang interaksi manusia dengan alam yang dipengaruhi oleh aktivitas seisme melalui gambar.

Berdasarkan jabaran indikator dari kompetensi pengetahuan pada materi litosfer tersebut, maka dapat dijelaskan bahwa masingmasing indikator memiliki kesesuaian apabila diterapkan dengan LKS berbasis learning cycle $5 E$. Indikator yang digunakan memiliki kesesuaian dengan tahap-tahap dalam learning cycle $5 E$ yaitu menganalisis interaksi manusia dengan alam yang dipengaruhi oleh aktivitas tektonis, membedakan gerak epirogenesa dengan gerak orogenesa, dan menganalisis interaksi manusia dengan alam yang dipengaruhi oleh aktivitas seisme sesuai dengan tahap pembangkitan minat (engagement) dan eksplorasi (exploration). Indikator selanjutnya yaitu membuat sajian tentang interaksi manusia dengan alam yang dipengaruhi oleh aktivitas tektonis melalui gambar, membuat sajian tentang interaksi manusia dengan alam yang dipengaruhi oleh aktivitas vulkanis melalui gambar, dan membuat sajian tentang interaksi manusia dengan alam yang dipengaruhi oleh aktivitas seisme melalui gambar sesuai dengan tahap menjelaskan (explaination), mengelaborasi (elaboration), dan 5) mengevaluasi (evaluation).

Pemilihan materi litosfer dalam penelitian ini didasarkan pada pertimbangan bahwa materi tersebut cocok dengan pengembangan LKS berbasis learning cycle 5E. Prinsip utama learning cycle adalah memusatkan pada usaha membantu siswa. Usaha tersebut dapat dilakukan dengan menggerakkan pengetahuan yang telah dimiliki dan membentuk ide didasarkan pada aktivitas pengamatan. Dengan bimbingan guru siswa membandingkan pikiran para ahli (guru maupun literatur) dengan hasil pengamatan. Selain itu, pertimbangan yang lain karena dalam materi litosfer memerlukan kegiatan untuk meningkatkan motivasi untuk mengetahui pengetahuan awal siswa, kegiatan eksplorasi, dan pemecahan masalah dengan proses berpikir secara berkelompok, seperti membedakan gerak epirogenesa dan orogenesa, tektonisme dan seisme. Syarat ini sangat penting karena berpengaruh langsung terhadap pembelajaran dan hasil akhirnya.

Hasil uji coba penggunaan LKS berbasis learning cycle 5E kategori tinggi pada kelompok kecil dan besar. Berdasarkan hasil tersebut maka dapat dijelaskan bahwa LKS geografi berbasis learning cycle $5 E$ pada materi pokok litosfer 
efektif untuk meningkatkan hasil belajar siswa. Hal ini sejalan dengan hasil penelitian Kulsum dan Hindarto (2011) menyatakan bahwa "learning cycle $5 E$ dapat meningkatkan keaktifan dan hasil belajar siswa dikarenakan kelebihan model pembelajaran learning cycle $5 E$ yang diutarakan siswa dapat membuat siswa lebih memahami konsep secara mandiri”. Songer dkk (2005) menjelaskan bahwa "penerapan learning cycle telah terbukti dapat meningkatkan pembelajaran sains". Sedangkan Hanuscin dan Lee (2007) dengan hasil penelitian memaparkan bahwa "learning cycle membantu siswa dalam memahami konsep yang dipelajari".

Penyebab LKS berbasis learning cycle 5E efektif dalam meningkatkan hasil belajar siswa dikarenakan LKS disusun secara sistematis dan berurutan dimulai dari kegiatan awal seperti mendatangkan pengetahuan awal dengan mengajukan pertanyaan-pertanyaan yang berkaitan dengan kehidupan sehari- hari sehingga menambah rasa ingin tahu siswa terkait materi. Dalam LKS ini tidak terdapat aktivitas siswa melakukan praktikum, tetapi digantikan dengan aktivitas siswa untuk memperoleh informasi baru atau pengetahuan yang baru dengan menampilkan gambar-gambar yang berkaitan dengan tektonisme, vulkanisme dan seisme, sehingga siswa membuat keinginantahuan siswa. Beberapa kegiatan LKS diharapkan dapat meningkatkan pemahaman siswa mengenai materi yang diajarkan dan mewujudkan tujuan pembelajaran. Dengan adanya keterkaitan antara isi dari aspek-aspek penyusunan LKS hasil pengembangan, maka pembelajaran dengan LKS berbasis learning cycle $5 E$ efektif untuk pembelajaran geografi karena didukung adanya peningkatan pada hasil belajar.

Sintak pembelajaran pada model learning cycle terdiri dari berbagai kegiatan kontruktivisme yang dalam pembelajarannya mengajak siswa untuk aktif. Apabila siswa aktif maka pengembangan suatu konsep dalam diri siswa dapat meningkat, yakni bagaimana pengetahuan dan keterampilan dapat dibangun dalam pikiran siswa, menemukan pengetahuan secara bermakna serta mengaitkan antara pengetahuan lama dengan pengetahuan baru untuk diaplikasi-kan dalam kehidupan sehari-hari. Suprapta (2006) menjelaskan bahwa "learning cycle membantu siswa bertanya, diskusi, berargumentasi, menyimpulkan atau merevisi pengertian konsep (concepts constructioned understanding)". Selain itu, Sari dan Handoyo (2018) menjelaskan bahwa "penyusunan bahan ajar LKS diarahkan pada penguasaan keterampilan abad 21. Dimana pada abad 21 siswa dituntut untuk memiliki kompetensi dengan indikator pemikiran tingkat tinggi yaitu menganalisis (C4), mengevaluasi (C5), dan mencipta (C6)".

\section{SIMPULAN}

Produk LKS berbasis learning cycle $5 E$ pada materi pokok litosfer ditinjau dari kelayakan isi, kebahasaan, penyajian, dan kegrafikan secara keseluruhan memiliki kriteria "tinggi" dan layak digunakan dalam pembelajaran geografi.

\section{DAFTAR PUSTAKA}

BSNP. 2006. Standar Isi Kurikulum Geografi. Jakarta: Depdiknas.

Hanuscin, Deborah L. and Michele H. Lee. 2007. Using a Learning Cycle Approach to teaching the Learning Cycle to Preservice Elementary Teachers. Association for Science Teacher Education. University of MissouriColumbia

Khanifatul. 2013. Pembelajaran Inovatif Strategi Mengelola Kelas secara Efektif dan Menyenangkan. Jogjakarta: Ar-Ruzz Media.

Kulsum, U \&amp; Hindarto, N. 2011. Penerapan Model Learning Cycle Pada Sub Pokok Bahasan Kalor Untuk Meningkatkan Keaktifan dan Hasil Belajar Siswa Kelas VII SMP. Jurnal Pendidikan Fisika Indonesia.7 (2011): 128-133

Prastowo, Andi. 2011. Panduan Kreatif Membuat Bahan Ajar Inovatif: 
Menciptakan Metode Pembelajaran yang Menarik dan Menyenangkan. Jogjakarta: DIVA Press.

Prastowo, Andi. 2011. Metode Penelitian Kualitatif dalam Perspektif Rancangan Penelitian. Jogjakarta: Ar-Ruzz Media.

Sari, Yuli Ifana \& Handoyo, Budi. 2018. A Preliminary Research to Develop 21th Century Worksheet. Advances in Social Science, Education and Humanities Research, volume 320. 1st International Conference on Social Knowledge Sciences and Education (ICSKSE 2018). Atlantis Press.

Songer, Nancy Butler \& Pier, Sun Ho. 2005. Guiding the "Explain": A Modified
Learning Cycle Approach Towards Evidence on the Development of Scientific Explanations. School of Education the University of Michigan.

Suprapta, I Made. 2006. Pengaruh Metode Pembelajaran (Siklus Belajar vs Konvensional) dan Motivasi Berprestasi Terhadap Hasil Belajar Biologi Pada Siswa Kelas 1 SMPN 1 Woja Dompu. Tesis tidak diterbitkan. Malang: PPs UM.

Turmudi. 2016. Pengembangan Model Pembelajaran Matematika SMP Berbasis Skafolding Metakognitif. Disertasi. Program Studi Pendidikan Matematika, Pascasarjana Universitas Negeri Malang. 